\title{
VU hidrometeorologijos specialybės studentų baigiamųjų darbų analizė klimato kaitos diskurso kontekste
}

\author{
Gintaras Valiuškevičius \\ Vilniaus universitetas, \\ M. K. Čiurlionio g. 21, LT-03101 Vilnius \\ El.paštas: gintaras.valiuskevicius@gf.vu.lt
}

\begin{abstract}
Valiuškevičius G. VU hidrometeorologijos specialybės studentų baigiamųju darbų analizė klimato kaitos diskurso kontekste. Geologija. Geografija. 2015. T. 1(1). ISSN 2351-7549.

Straipsnyje pateikiami 1994-2013 m. Vilniaus universiteto hidrometeorologijos studijų programos studentų baigiamųjų darbų struktūrą apibūdinančių charakteristikų analizės rezultatai. Kartu siekiama apibūdinti akademinio klimato kaitos diskurso specifiką. Nustatyta, kad nagrinètų darbų tematika ir struktūra bei klimato kaitos sąvokos statusas juose tiriamuoju laikotarpiu pakito dèl informacinès ir technologinès plètros. Rodikliai ypač pakito antroje laikotarpio pusèje: maždaug nuo 2003-2005 m. darbuose pradèta dažniau analizuoti meteorologijos-klimatologijos klausimus (anksčiau dominavo hidrologinès temos), naudoti stacionarių nuolatinių matavimų rezultatus, nagrinèti ilgesnes duomenų sekas, cituoti daugiau literatūros šaltinių anglų kalba. Tyrimas rodo, kad baigiamuosius darbus studentai linkę traktuoti kaip aukšto lygio specializuotus mokslinius tekstus ir juose vengia nepagrịstai vartoti savitus terminus. Dèl argumentų stygiaus terminas „klimato kaita“ dažniausiai vartojamas darbų ịvade, dar nepradèjus nagrinèti konkrečių rezultatų.
\end{abstract}

Raktažodžiai: klimato kaita, akademinis diskursas, hidrometeorologija, baigiamieji darbai

\section{IVADAS}

Intensyviai vykstanti klimato kaita paskatino visuotinị susidomejjimą hidrometeorologiniais tyrimais. Tarpvyriausybinès klimato kaitos komisijos (angl.: The Intergovernmental Panel on Climate Change, IPCC) ataskaitos, anksčiau dominusios tik specialistus, aptarinejjamos žiniasklaidoje, jų duomenys naudojami politiniuose debatuose bei reklamoje (Risbey, 2008; Asayama, Ishii, 2012). Padidejusi hidrometeorologinès informacijos visuomeniškumą pastebejo ir socialinių mokslų atstovai: imta nagrinèti šiais duomenimis paremtų viešųjų diskursų formavimąsi, su jais siejamų politinių sprendimų priemimo klausimus (Brossard ir kt., 2004; Boykoff, Boykoff, 2007; Doyle, 2007; Anderson, 2009). Lietuvoje šie tyrimai ypač suintensyvejo vykdant projektą „RINOVA: Rizikos suvokimas, viešoji komunikacija ir inovatyvus valdymas žinių visuomeneje“ (2009). Remiantis jo duomenimis bei vèlesnèmis studijomis, paskelbta daugybė darbų, analizuojančių hidrometeorologiniais argumentais grindžiamus viešosios polemikos atvejus (Balžekienė ir kt., 2008; Balžekienè ir kt., 2009; Telešienè, 2009; Jančevskaitè, Telešienè, 2013).

Tyrimai Lietuvoje labiau orientuoti $\mathfrak{i}$ tiesiogiai visuomenès nuomonę veikiančių (išorinių) veiksnių analizę: nagrinèta klimato kaitos rizikos samprata visuomeneje bei žiniasklaidos poveikis jai. Vidinès diskurso aplinkybės (klimatologų ir gretimų sričių specialistų nuomonè, jos pokyčiai ir ju priežastys) šalyje netirtos. Tokị sociologų požiūrị išsamiai paaiškino A. Telešienè (2009): „Visuomenès kolektyvinè sąmoné, kurioje vietą randa ir klimato kaitos reiškinio reprezentacijos, yra tarsi 
kreivas veidrodis, labiau atspindintis socialiai konstruojamus, nepatvirtintus, gandų ir įsitikinimų lygmens vaizdinius apie klimato kaitą nei klimatologu moksliniais tyrimais patvirtintus faktus apie realiai vykstančius klimato pokyčius.“ Kita vertus, „kreivame veidrodyje" matomi vaizdiniai dažnai genetiškai susiję su konkrečių mokslo sričių tyrimų rezultatais. Bendras tendencijas, būdingas klimato kaitos diskursams moksle, politikoje ir žiniasklaidoje pastebejo daugelis šią temą tyrusių autorių (Weingart ir kt., 2000; Asayama, Ishii, 2012; Jaspal ir kt., 2013). Sąsajas tarp mokslinių paradigmų ir visuomenès nuomonès pokyčiu nagrinèję tyrèjai teigia, kad šias pasaulio sampratos struktūras - nepriklausomai nuo tematikos - sieja abipusis ryšys (Agazzi, 2004). Specialistų nuomonès svarbą gamtiniu procesų suvokimui visuomeneje patvirtina ir Lietuvoje atlikti tyrimai: 2009-2011 m. „Lietuvos ryto" dienraštis mokslininkus ir specialistus, kaip informacijos šaltini, mini $46 \%$, o portalas , Irytas. $1 t^{\text {“ }}-68 \%$ straipsnių klimato kaitos tema (Jančevskaitè, Telešienè, 2013). Net žiniasklaidai nurodant kitus informacijos šaltinius (politikus, visuomenès veikejjus, naujienų agentūras) pradinè pranešimo idejja dažnai konstruojama remiantis moksliniais duomenimis. Tad ekspertai, vykdantys su klimato kaita susijusius tyrimus, - vieni iš svarbiausių šios srities žiniasklaidos diskurso veikejų.

Lietuvoje stinga darbų, nagrinėjančių socialinị suvokimą apie klimato kaitą formuojančios bazinès informacijos turinị: hidrometeorologinių tyrimų rezultatus, jų tikslus, metodus, sklaidos galimybes. Šie duomenys padètų geriau suprasti daugelio (ne tik su klimato kaita susijusių) viešųjų diskursų konstravimo ir net atsiliepimo i juos procesus. Be abejo, tokio masto apžvalgos laukas - pernelyg platus vienam straipsniui. Tad darbe apsiribota svarbiausių tyrimų pobūdžio dèsningumų (objektų, metodų, arealo ir pan.) analize. Tai padeda pažinti bendrą Lietuvos hidrometeorologinių tyrimų mokslinès paradigmos formatą bei išryškinti su klimato kaitos mokslinio diskurso vystymusi susijusius darbų struktūros pakitimus. Straipsnio tikslas - išnagrinèti Vilniaus universiteto Hidrologijos ir klimatologijos katedros (VU HKK) absolventų paskutiniųjų dvidešimties metų baigiamųjų darbų struktūros rodiklius ir jų pokyčių priežastis. Kartu stengtasi apibūdinti klimato kaitos akademinio diskurso ir jo raidos ypatumus.

\section{TYRIMO OBJEKTO PASIRINKIMO APLINKYBĖS}

Analizuojant tyrimų tematikos ir metodikos kaitą, būtina ilgalaikè homogeniška informacija. Tyrimui panaudoti VU HKK absolventų baigiamieji darbai. Pasirinkimą iš dalies lèmé informacijos stoka: Lietuvoje nèra geriau hidrometeorologijos žinių ir mokslinio požiūrio kaitą apibūdinančios ir vientisa struktūra pasižyminčios duomenų bazès. Moksliniai straipsniai išsklaidyti žurnaluose, skirtuose platesnei (geografijos, geologijos, energetikos, ekologijos, žemès ūkio, inžinerijos ir pan.) tematikai. Vieninteli šalyje leidini, skirtą hidrometeorologiniams tyrimams („Hidrometeorologiniai straipsniai“), nustota leisti daugiau kaip prieš 20 metų, o Lietuvos tyrejjų mokslinė produkcija užsienio žurnaluose - negausi ir sunkiai pasiekiama.

Mokslines publikacijas sunku analizuoti ir todèl, kad vertinant ịvairiomis kalbomis ar kelių autorių parašytus straipsnius stinga objektyvių kriterijų. Nustatyta, kad apibūdinant mokslo minties raidą pagal citavimo indeksus, nuošalejje lieka mažiau aktualiais klausimais bei nacionaline kalba rašantys autoriai (Garfield, 1983; Hirsch, 2005). Žinant, kaip XXI a. išaugo publikacijų anglų kalba skaičius fizinių mokslų srityje bei atsižvelgiant i tai, kad hidrometeorologų straipsniuose iprasta nagrinèti konkrečių regionų problemas, manytina, kad citavimo indeksai neleistų korektiškai ịvertinti tyrimų konteksto pokyčių. Šio tipo tyrimuose objektyvieji bibliometriniai kriterijai dažnai yra antraplaniai, nes vertinant mokslinès minties pažangą svarbu išryškinti ne tik pokyčiu mastą, bet ir kryptị bei juos sukèlusius veiksnius. Tai ypač svarbu apibūdinant specialistų požiūrio, formuojančio visuomenès žinias apie jų tyrimų sritị, pokyčius (Augustinaitis, 2004). Apsiriboti statistiniu mokslo straipsnių ir jų citavimo vertinimu neleidžia ir menkas analizuojamosios pažinimo srities istorijos ištirtumas. Kaip rodo kitų autorių patirtis (Kraniauskas, 2001), analizuojant mokslo tradiciją regioniniame kontekste svarbu atsižvelgti ne tik $\mathfrak{i}$ pateikiamos produkcijos kiekybinę dinamiką, bet ir $\mathfrak{i}$ kokybinius pokyčius tekste.

Baigiamieji darbai reprezentatyviai atspindi tyrimų koncepcijos raidą, nes VU HKK - vienintelè katedra Lietuvoje, rengianti diplomuotus hidrometeorologus (čia išugdyti beveik visi aktyviai dirbantys šios srities šalies specialistai). Svarbus jos 
absolventų mokslinis ịdirbis: apie 70 \% (38 iš 55) po $1970 \mathrm{~m}$. Lietuvoje apgintų hidrometeorologinès tematikos disertacijų autorių yra baigę VU HKK (Lietuvos geografų draugija, 2014). Baigiamųjų darbų rengimo principai VU HKK tiriamuoju laikotarpiu beveik nekito, tad tyrimas atspindi ir bendrą šios srities mokslo idejų diapazoną Lietuvoje.

\section{TYRIMO METODIKA}

Empirinis tyrimas paremtas VU HKK absolventu baigiamųjų darbų kiekybine bei kokybine analize. VU HKK archyve saugomi nuo $1931 \mathrm{~m}$. katedroje apginti baigiamieji darbai yra trijų tipų (diplominiai, bakalauro ir magistro), nes 1992-1996 m., vykdant studijų reformą, hidrometeorologijos studijų sistema pertvarkyta iš vienpakopès ị dvipakopę. Darbų skirstymas i tris tipus - gana sąlyginis, nes visi šie darbai laikytini ir baigiamaisiais, ir diplominiais. Tačiau tolimesniame straipsnio tekste (siekiant paprastumo) diplominiais vadinami esant vientisujų studijų sistemai apginti baigiamieji darbai, o magistro darbais - antrosios studiju pakopos (magistrantūros) baigiamieji darbai. Kalbant apie visus (tiek magistro, tiek diplominius) darbus, vartojamas terminas „baigiamieji darbai“.

Analizei panaudoti diplominiai (vientisųjų studijų) ir magistro (antrosios studijų pakopos) darbai, apginti VU HKK nuo 1994 iki 2013 m. Bakalauro darbai neanalizuoti, nes jiems keliami reikalavimai šiek tiek skiriasi nuo reikalavimų, keltų diplominiams darbams. Iki 1994 m. apginti darbai nenagrinèti dèl techninių sunkumų (dauguma jų spausdinti rašomąja mašinèle) ir per ilgą laikotarpi ịvykusių esminių darbo struktūros pokyčių (anksčiau darbuose nebuvo privalomi literatūros apžvalgos ir darbo metodikos skyriai). Analizei panaudotas 101 baigiamasis darbas (10 diplominių ir 91 magistro). Didesnè dalis darbų autorių (60 iš 101) - moterys. Tyrimo metu vertinta darbų tematika, apimtis, struktūra, informatyvumas, duomenų kilmè ir formatas, nagrinèto laikotarpio trukme ir tyrimo teritorinis mastas. Analizuotas visų darbų turinys, ịvadas, metodikos skyrius, išvados ir santrauka. Pristigus informacijos, analizei kartais naudota ir kituose darbų skyriuose pateikta medžiaga. Svarbiausių skyrių (ịvado, išvadų, literatūros sąrašo) struktūra analizuota išsamiau ir apibūdinta kiekybiniais rodikliais (išvadų skai- čius, literatūros šaltinių ịvairiomis kalbomis skaičius ir pan.). Nagrinejjant turinio pokyčius atskirai apibendrinta keturis 5 metų trukmès laikotarpius (1994-1998, 1999-2003, 2004-2008, 2009-2013) apibūdinanti informacija.

Tiriant klimato kaitos ir ją charakterizuojančių rodiklių pateikimą baigiamuosiuose darbuose daugiau dèmesios skirta kokybinei analizei. Nagrinètos termino „klimato kaita“ pateikimo vietos (ivade, metodinèje dalyje, išvadose) ir tikslai (méginimai susieti informaciją su platesniu kontekstu, aktualizuoti tematiką, apibūdinti darbo objektą). Konkretesni šios analizès dalies metodinị aprašymą galima rasti skyriuje „Su klimato kaita susijusių terminų pateikimas“. Detaliam kiekybinių rodiklių tyrimui, nagrinejjant klimato kaitos akademini diskursą, pristigo informacijos (kaip parode tyrimas, terminas baigiamuosiuose darbuose minimas gana retai). Analizès rezultatus bandyta palyginti su bendruoju baigiamųjų darbų kontekstu ir jo pokyčiais.

\section{BENDRIEJI DARBŲ TURINIO IR KONTEKSTO BRUOŽAI}

Dauguma VU HKK absolventų baigiamųjų darbų skirti siauriems konkrečios temos klausimams (Vilniaus universiteto Hidrologijos..., 2014), tad jų tematiką atspindi nagrinèti rodikliai. Pagrindines hidrometeorologinių tyrimų sferas galima atskirti pagal objektą: hidrologinès tematikos darbuose analizuojamos hidrosferos, o meteorologinès-klimatologinès tematikos darbuose - atmosferos charakteristikos. (Tolimesniame tekste, siekiant neišsiplèsti, ir meteorologijos, ir klimatologijos klausimus nagrineję darbai bus vadinami meteorologiniais.) Hidrologinès ir meteorologinès tematikos darbų skaičius tiriamuoju laikotarpiu buvo panašus (atitinkamai 52 ir $48 \%$ ), bet jų tarpusavio santykis nuo laikotarpio pradžios smarkiai pakito (1 lentelè).

Ryškiausias tematikos pokytis ivyko apie 20022005 m.: 1994-2003 m. daugiau kaip du trečdaliai darbų skirta hidrologijos problemoms, o 20042013 m. dauguma darbų nagrinejo meteorologijos klausimus. Studijų programos pokyčiai 19942013 m. buvo nežymūs (atmosferos ir hidrosferos analizei skirtu studiju dalyku santykis beveik nepakito). Pernelyg smarkiai nesikeitè ir darbų vadovų tyrimų sritys. Tad darbų tematikos akivaizdžias 
1 lentelè. Tam tikrais rodikliais pasižyminčių VU HKK baigiamụjų darbų dalis (\%) nuo bendro jų skaičiaus 1994-2013 m.

Table 1. The part of VU HKK theses with particular characteristics (\%) of the total number of theses from 1994 to 2013

\begin{tabular}{|c|c|c|c|c|c|c|c|c|c|c|c|c|c|}
\hline \multirow[b]{2}{*}{ 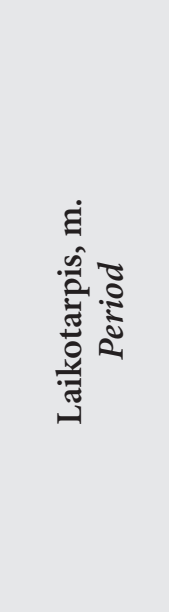 } & \multirow{2}{*}{ 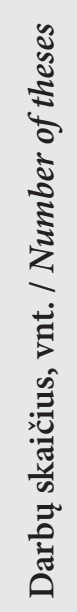 } & \multicolumn{2}{|c|}{$\begin{array}{c}\text { Nagrinèti } \\
\text { rodikliai } \\
\text { Analysed } \\
\text { characteris- } \\
\text { tics }\end{array}$} & \multicolumn{3}{|c|}{$\begin{array}{l}\text { Naudotų duomenų } \\
\text { kilmé } \\
\text { Data source }\end{array}$} & \multicolumn{4}{|c|}{$\begin{array}{c}\text { Nagrinèto laikotarpio } \\
\text { trukmé } \\
\text { Research period }\end{array}$} & \multicolumn{3}{|c|}{$\begin{array}{l}\text { Tyrinètas regionas } \\
\text { Research region }\end{array}$} \\
\hline & & 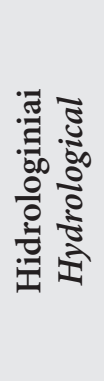 & 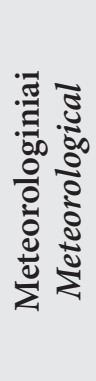 & 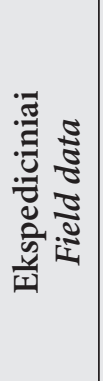 & 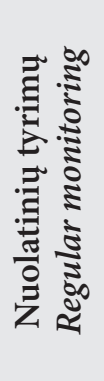 & 寻 & 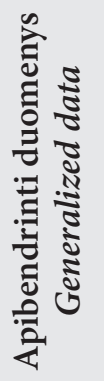 & 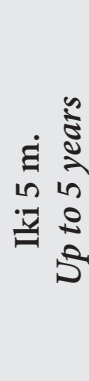 & 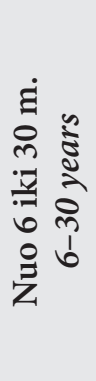 & 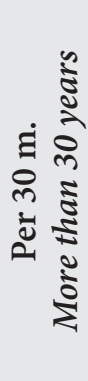 & 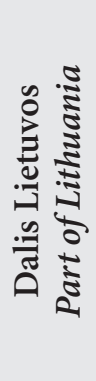 & 氞 & 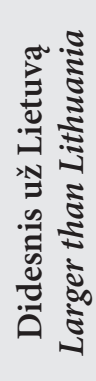 \\
\hline 1994 & 16 & 8,8 & & 12,5 & & & 12,5 & & & & 50 & & 18,7 \\
\hline & 30 & 66,7 & 33, & 20,0 & & & 16 & 13,3 & 43 & & 46,7 & 3 & 10,0 \\
\hline 2004-2008 & 19 & 36,8 & 63,2 & 5,3 & 84, & 10,5 & 10,5 & 5, & 47 & 36,8 & 42,1 & 36,8 & 21,1 \\
\hline $2009-2013$ & 36 & 36,1 & 63,9 & 5,6 & 83,3 & 11,1 & 5,6 & 5,6 & 44 & 44,4 & 22,2 & 55,6 & 22,2 \\
\hline 1994-2013 & 101 & 52,1 & 47,9 & 10,9 & 74,1 & 15,0 & 11,3 & 9,2 & 46,3 & 33,2 & 40,2 & 41,8 & 18,0 \\
\hline
\end{tabular}

permainas didžia dalimi galima sieti su studentų nuomonès apie tyrimų igyvendinimo galimybes ir aktualumą pokyčiais.

Stacionariais nuolatiniais tyrimais paremtų darbų skaičius staigiai pakito apie 2003-2004 m. (1994-2003 m. jie sudare 64,4\%; o 20042013 m. - 83,7\%). Tai sietina su elektroninio informacijos formato ir interneto pletros nulemtais paradigminiais hidrometeorologinių tyrimų konteksto pokyčiais. Žemès mokslai (aplinkotyra, geologija, hidrometeorologija ir pan.) pasaulyje, paplitus kompiuterinems technologijoms, patyrẻ ryškų „požiūrio lūží. Manoma, kad hidrometeorologiją ypač paveikè naujos informacijos apdorojimo ir palyginimo galimybès, kurias atskleidè programinès įrangos ir interneto plètra (Hansen ir kt., 2009; Hunt ir kt., 2009). Šios srities tyrimams Lietuvoje minèti pokyčiai ịtakos turèjo paskutiniajame XX a. dešimtmetyje (Valiuškevičius, 2001). Nuo XXI a. pradžios informacinès ir technologinès plètros poveikis juntamas ir VU HKK absolventų baigiamuosiuose darbuose.

Maždaug $74 \%$ nagrinètų darbų paremti nuolatinių hidrometeorologinių matavimų duomenimis, sukauptais reguliarų monitoringą vykdančių organizacijų (Lietuvos hidrometeorologijos tarnybos, Aplinkos apsaugos agentūros ir pan.) archy- vuose. Apie $11 \%$ darbų remiasi studentų ekspedicinių matavimų medžiaga, o $15 \%$ - tiesiogiai su hidrometeorologiniais matavimais nesusijusiais rodikliais (kartografine, istorine medžiaga ir pan.). Nuo tiriamojo laikotarpio pradžios darbų, kuriuose nenaudoti hidrometeorologinių matavimų duomenys, skaičius nuolat mažèjo, o stacionarių matavimų rezultatus naudojančių darbų dalis smarkiai išaugo (1 lentelè).

Tai rodo ir ryškūs darbuose nagrinèjamų duomenų apimties pokyčiai (1 pav.). Dažniausiai (46,3 \% baigiamųų darbų) VU HKK absolventai 1994-2013 m. nagrinèjo 6-30 m. trukmès laikotarpius reprezentuojančias duomenų sekas. Tačiau tiriamuoju laikotarpiu nuolat daugejjo darbų, nagrinejjančių ilgesnius kaip $30 \mathrm{~m}$. laikotarpius. 1994-2013 m. smarkiai kito ir darbuose analizuojamo arealo plotas. Ši charakteristika apibūdina teritorijos ištirtumo lygmenị ir atskleidžia metodines tyrimų srities galimybes. Dauguma nagrinètų darbų apibūdina visą Lietuvos teritoriją (41,8 \%) arba jos dalį (40,2 \%). Tiriamojo laikotarpio pradžios darbuose dažniausiai aptariama tik dalis Lietuvos teritorijos (naudojami vienos ar kelių meteorologijos arba hidrologijos stočiu duomenys), o pastaraisiais metais tiriama visa šalies teritorija ar dar didesnis regionas (1 pav.). Kita vertus, 
Meteorologinès ir klimatologinès tematikos darbai /Theses of meteorological and climatological topics

Ilgesni kaip $30 \mathrm{~m}$. laikotarpi nagrinejjantys darbai / Theses which analysed more than 30 years period

m Darbai, kuriuose nagrinèjama tik dalis Lietuvos teritorijos / Theses which analysed only part of Lithuania

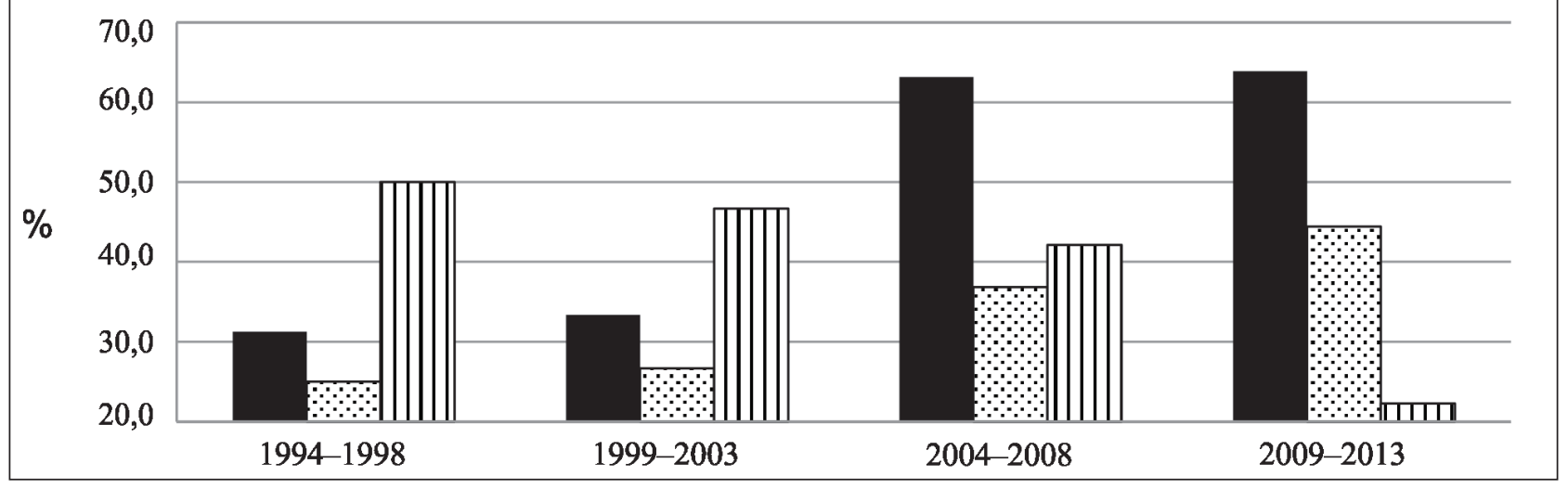

1 pav. VU HKK absolventų baigiamųjų darbų tematikos ir juose nagrinëjamų duomenų apimties kaita (tam tikrais požymiais pasižyminčių darbų dalis, \% nuo bendro darbų skaičiaus)

Fig. 1. VU HKK theses subject area and change of their data amount (part of theses with particular characteristics in $\%$ of the total number of theses)

analizuojant hidrometeorologinio pobūdžio mokslinius darbus dažnai sunku apibrèžti tikslias nagrinejjamos teritorijos ribas. Todèl šiame straipsnyje laikytasi gana "grubaus“ darbų skirstymo principo: dalį Lietuvos nagrinejusiais darbais laikyti visi, kuriuose neaptikta palyginamosios teritorijos analizès požymių (nèra nagrinėjamų rodiklių žemèlapių, analizuojamos ne daugiau kaip dvi stotys arba vienas konkretus baseinas), tokius požymius turintys darbai laikyti nagrinejjusiais visą Lietuvą, o darbai, lyginantys Lietuvos ir kitų regionų sąlygas, - nagrinejjusiais didesnị už Lietuvą regioną. Tad dalies baigiamujuc darbų (pvz., analizuojančių nedidelès upès baseiną, kurio ribos tęsiasi už Lietuvos, arba tiriančių dviejų meteorologijos stočių, viena iš kurių ịsikūrusi užsienyje, duomenis) priskyrimas vienai ar kitai kategorijai gana subjektyvus.

Tiriamuoju laikotarpiu taip pat sumažejo darbų, naudojančių kitų autorių apibendrintus (vidutinius tam tikro laikotarpio ar teritorijos) duomenis (1 lentelè). Naujos informacijos gavimo ir apdorojimo galimybès paveikè ir darbų temati$\mathrm{ką}$ - absolventai èmè dažniau rinktis daug pradinès medžiagos reikalaujančius meteorologijos srities tyrimus (kurių anksčiau vengta dèl techninių kliūčių). Informacijos panaudojimo galimybių plètra atsispindi darbų struktūros pokyčiuose. Bendrosios darbo dalies apimtis ir skyrių skaičius joje beveik nesikeitè, tačiau išaugo teksto informatyvu- mo ir iliustratyvumo rodikliai: paveikslų, lenteliu skaičius, skaitines vertes pateikiančių išvadų dalis (2 lentelè). Kai kurie duomenys aiškiai charakterizuoja autorių komunikacijos pobūdžio pokyčius. Darbuose cituojamuose literatūros šaltiniuose nuo tiriamojo laikotarpio pradžios iki pabaigos beveik išnyko tekstai rusų kalba, smarkiai sumažèjo lietuviškų šaltinių dalis ir èmé dominuoti straipsniai bei knygos anglų kalba. Bendras darbuose cituojamų šaltinių skaičius 1994-2013 m. nuolat augo. Tai lèmé pasikeitęs ịvairių kalbų mokejimo lygis ir mokslinès literatūros paieškos internete galimybès. Dèl analogiškų priežasčių per 20 metų dvigubai išaugo literatūros apžvalgai skiriamos darbo dalies apimtis.

\section{SU KLIMATO KAITA SUSIJUSIŲ TERMINŲ PATEIKIMAS}

Tyrimo metu mėginta išryškinti ir svarbiausias akademinio klimato kaitos diskurso charakteristikas. Specifinès srities moksliniai tekstai pasižymi standartiniu pateikimo formatu, yra skirti siauram skaitytojų ratui ir rašomi siekiant konkretaus tikslo. Lingvistinių diskurso rodiklių tyrejjai pabrěžia, kad šie tekstai kuriami naudojant aiškų strategini modelį, kas lemia konkrečių leksinių vienetų vartojimo specifiką (Šinkūnienè, 2010). Analizuojant juos netinka tradiciniai metodai, taikomi žiniasklaidoje 
2 lentelè. VU HKK baigiamųjų darbų struktūrą 1994-2013 m. apibūdinantys rodikliai (vidutinès reikšmès ivairiais laikotarpiais)

Table 2. The characteristics describing the VU HKK theses structure in 1994-2013 (mean values in different periods)

\begin{tabular}{|c|c|c|c|c|c|c|c|c|c|c|c|c|c|c|c|c|c|}
\hline \multirow[b]{3}{*}{ 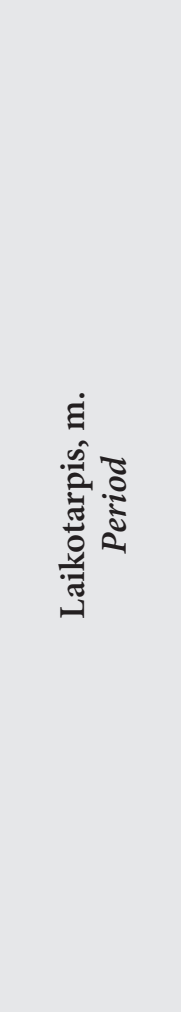 } & \multirow{2}{*}{\multicolumn{4}{|c|}{$\begin{array}{l}\text { Teksto apimtis, } \mathrm{p} \text {. } \\
\text { Text corpus, } p p \text {. }\end{array}$}} & \multirow{2}{*}{\multicolumn{3}{|c|}{$\begin{array}{c}\text { Infor- } \\
\text { macijos } \\
\text { papildymo } \\
\text { formos, vnt. } \\
\text { Amount of } \\
\text { additional } \\
\text { information }\end{array}$}} & \multicolumn{7}{|c|}{$\begin{array}{l}\text { Naudotų literatūros šaltinių skaičius } \\
\text { Number of references }\end{array}$} & \multicolumn{3}{|c|}{$\begin{array}{c}\text { Išvadų skaičius } \\
\text { Number of } \\
\text { conclusions }\end{array}$} \\
\hline & & & & & & & & \multirow[b]{2}{*}{ 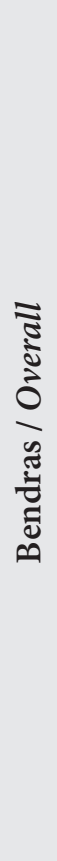 } & \multicolumn{2}{|c|}{ 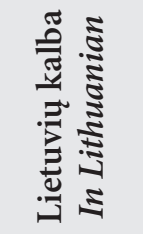 } & \multicolumn{2}{|c|}{ 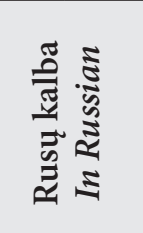 } & \multicolumn{2}{|c|}{ 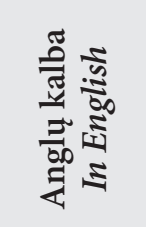 } & & \multicolumn{2}{|c|}{ 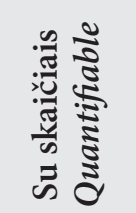 } \\
\hline & 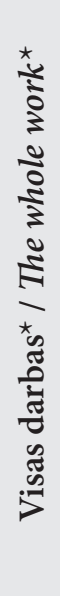 & 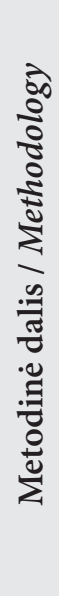 & 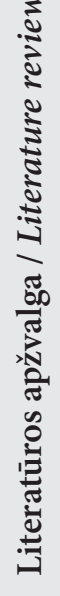 & 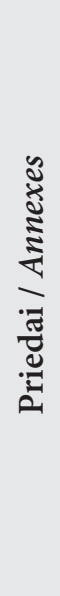 & 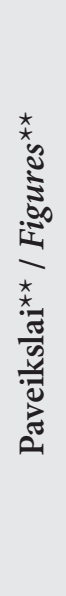 & 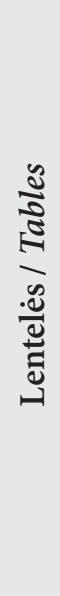 & 章 & & 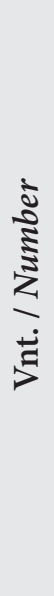 & de & 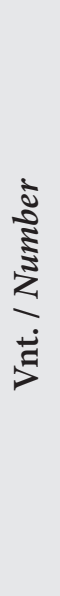 & de & 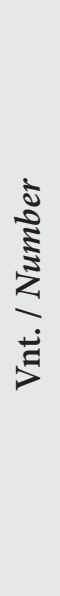 & $a^{e}$ & 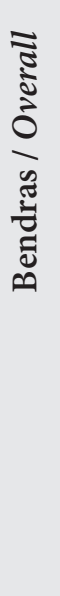 & 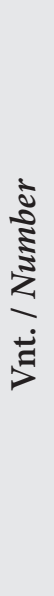 & $a^{0}$ \\
\hline 1994-1998 & 48 & 5 & 4 & 10 & 24 & 5 & 4 & 23 & 13 & 57 & 9 & 39 & 1 & 4 & 7 & 4 & 56 \\
\hline 1999-2003 & 57 & 4 & 5 & 22 & 26 & 11 & 7 & 36 & 17 & 47 & 8 & 22 & 10 & 28 & 9 & 5 & 52 \\
\hline 2004-2008 & 55 & 7 & 7 & 13 & 28 & 10 & 4 & 40 & 13 & 33 & 4 & 10 & 21 & 53 & 10 & 7 & 74 \\
\hline 2009-2013 & 59 & 6 & 8 & 25 & 31 & 12 & 4 & 49 & 17 & 35 & 2 & 4 & 29 & 59 & 8 & 7 & 82 \\
\hline 1994-2013 & 55 & 5 & 6 & 18 & 27 & 10 & 5 & 37 & 15 & 43 & 6 & 19 & 16 & 38 & 9 & 6 & 66 \\
\hline
\end{tabular}

* be priedų / without annexes; ${ }^{* *}$ paveikslai iš kelių dalių (a, b, c ir pan.) vertinti kaip vienas paveikslas / Figures with several parts $(a, b, c)$ assessed as one figure.

pateikiamiems rašiniams. Ne kartą pastebèta, kad aptariant klimato kaitą specialistai linkę išryškinti kitus aspektus nei žiniasklaidos atstovai. Medijos dažniau akcentuoja problemini šio klausimo ịvaizdị (nelaimès, katastrofos, sąlygu blogèjimas), o moksliniai tekstai pokyčių požymius vertina nepabrěždami jų poveikio (Hulme, 2006; Risbey, 2008).

Nagrinëjant klimato kaitos diskursą hidrometeorologų baigiamuosiuose darbuose, svarbu tiksliai apibrežti tyrimų objektą. Dauguma šių darbų analizuoja ịvairių atmosferos ir hidrosferos būklès rodiklių pokyčius. Terminai „temperatūros kilimas", „krituliu gausèjimas", „ekstremaliu atvejų padažnejjimas" ir pan. čia yra vieni iš svarbiausių ir dažniausiai vartojamų. Beveik visus tiriamus pokyčius vienaip ar kitaip galima susieti su klimato kaita, bet tiesiogiai šis terminas vartojamas ne itin dažnai. Tai lemia dvi priežastys: 1) hidrometeorologija atstovauja fizinių mokslų sričiai, taikančiai terminologijai griežtos argumentacijos reglamentą; 2) baigiamuosius darbus rašantys studentai yra issisavinę specifinę terminiją, leidžiančią tiksliai apibūdinti konkrečių rodiklių kitimą, nevartojant sunkiai pagrindžiamos „klimato kaitos“ sąvokos.

Platus baigiamuosiuose darbuose vartojamų terminų diapazonas bei dažnumas ribojo tyrimo galimybes. Todèl tiriant klimato kaitos diskursą nagrinèti tik reikšminiai baigiamųjų darbų skyriai, apibūdinantys dažniausiai darbe nagrinèjamas temas (ivvadas, išvados, santrauka). Juose analizuoti termino "klimato kaita“ atvejai. Papildomai nagrinetas šio termino vartojimas apibrěžiant darbo tikslus ir uždavinius bei darbų ar atskirų jų skyrių pavadinimuose. 
Tyrimo pobūdis neleido detaliai išanalizuoti diskurso objektą charakterizuojančių indikatorių, todèl daugiau dèmesio skirta klimato kaitos sąvokos vartojimo kontekstui.

Išnagrinejjus 101 darbą paaiškejo, kad „klimato kaita" minima 35 darbų reikšminiuose skyriuose, o šio termino vartojimo dažnumas tiriamuoju laikotarpiu augo (3 lentelè). Tai rodo, jog su šia tema susiję tyrimai Lietuvoje laikomi perspektyviais ir veiksnių, motyvuojančių tyrejjus (tiek baigiamųjų darbų autorius, tiek vadovus), jų imtis, daugeja. Klimato kaita žymiai dažniau minima meteorologinius rodiklius analizuojančiuose darbuose (terminas aptinkamas $44 \%$ šių darbų), nei darbuose, skirtuose hidrologinei tematikai (25\%). Nustatyta, kad terminą "klimato kaita“ minintys darbai yra platesnès apimties, pasižymi didesniu informatyvumu ir iliustratyvumu, juose skiriama daugiau dèmesio literatūros apžvalgai ir tyrimu metodikos aprašymui (2 pav.). Klimato kaitą mininčiuose

3 lentelè. Baigiamụjų darbų, kurių reikšminiuose skyriuose vartojamas „klimato kaitos“ terminas, pasiskirstymas pagal minejjimo vietą ir laikotarpị: $\mathbf{n}$ - vnt., \% - dalis nuo bendro baigiamųjų darbų skaičiaus (dalyje darbų terminas minimas keliuose skyriuose)

Table 3. The distribution of theses with the term "climate change" in basic chapters (n-number of theses, \%-part of the total number of theses)

\begin{tabular}{|c|c|c|c|c|c|c|c|c|c|c|}
\hline \multirow{4}{*}{$\begin{array}{l}\text { Laikotarpis, m. } \\
\quad \text { Period }\end{array}$} & \multicolumn{10}{|c|}{$\begin{array}{c}\text { Darbų, kurių reikšminiuose skyriuose minimas „klimato kaitos“ terminas, skaičius } \\
\text { Number of theses with term “climate change” in basic chapters }\end{array}$} \\
\hline & \multirow{2}{*}{\multicolumn{2}{|c|}{$\begin{array}{l}\text { Bendras } \\
\text { Overall }\end{array}$}} & \multicolumn{8}{|c|}{ Skyriai, kuriuose minimas terminas / Parts of the theses } \\
\hline & & & \multicolumn{2}{|c|}{$\begin{array}{l}\text { Ivadas } \\
\text { Introduction }\end{array}$} & \multicolumn{2}{|c|}{$\begin{array}{l}\text { Tikslas ir uždaviniai } \\
\text { Aims and scopes }\end{array}$} & \multicolumn{2}{|c|}{$\begin{array}{l}\text { Išvados } \\
\text { Conclusions }\end{array}$} & \multicolumn{2}{|c|}{$\begin{array}{l}\text { Santrauka } \\
\text { Summary }\end{array}$} \\
\hline & n & $\%$ & $\mathbf{n}$ & $\%$ & $\mathbf{n}$ & $\%$ & n & $\%$ & n & $\%$ \\
\hline 1994-2003 & 11 & 26,8 & 8 & 17,4 & 3 & 6,5 & 7 & 15,2 & 3 & 6,5 \\
\hline $2004-2013$ & 24 & 43,6 & 21 & 38,2 & 11 & 20,0 & 13 & 23,6 & 5 & 9,1 \\
\hline
\end{tabular}

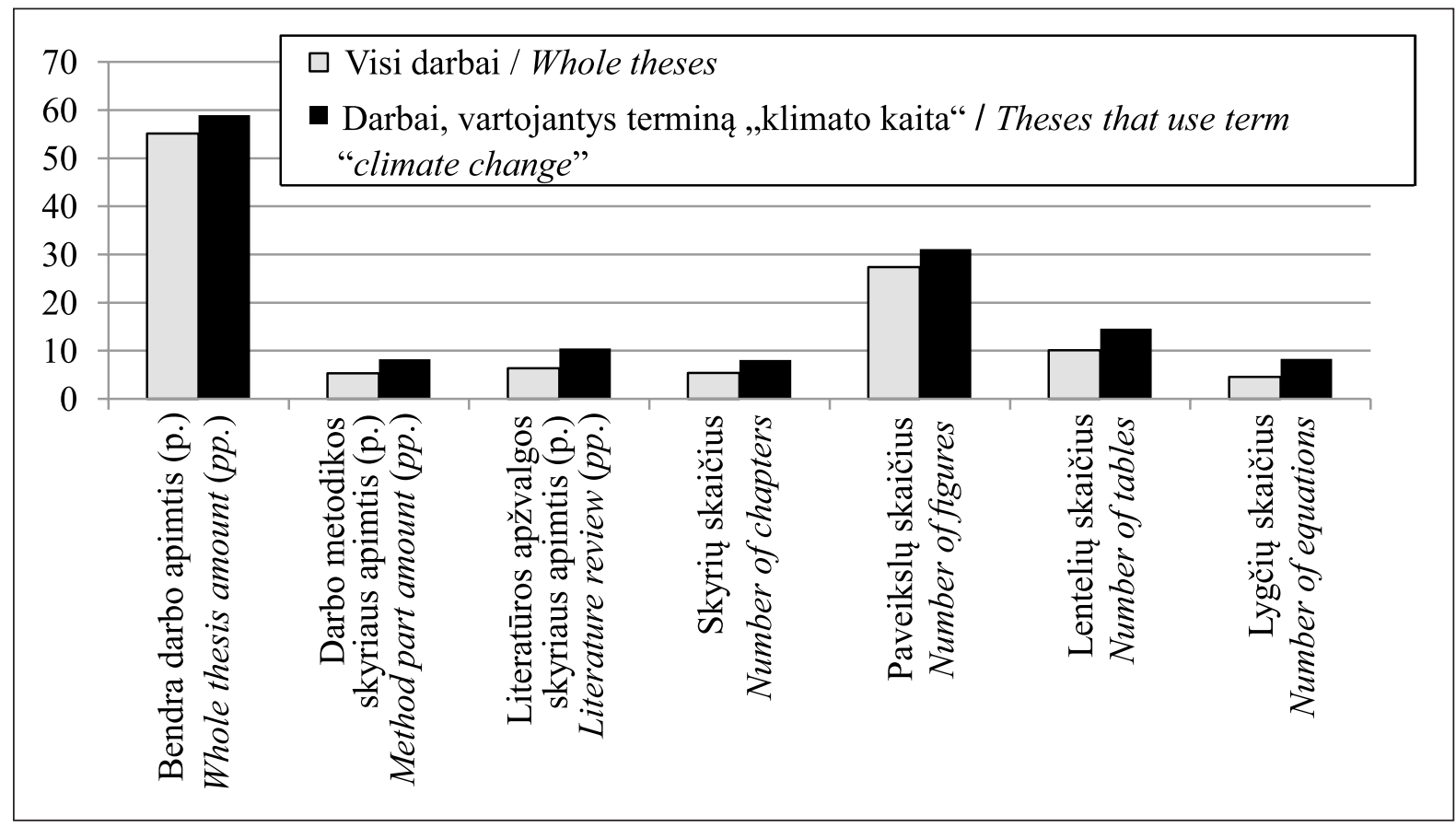

2 pav. Darbų, kuriuose vartojamas terminas „klimato kaita“, rodiklių palyginimas su visiems VU HKK baigiamiesiems darbams büdingais rodikliais

Fig. 2. The comparison of characteristics for theses with the term "climate change" with characteristics for all theses in VU HKK 
darbuose paprastai tirtos didesnès teritorijos: terminas vartojamas $42 \%$ visą Lietuvą, $50 \%$ didesni regioną ir tik $18 \%$ dali Lietuvos ploto nagrinejusių darbų. Tai sietina su klimato kaitos problemos globalumu (realūs šiuo terminu apibūdinamo proceso įrodymai išryškejja tik dideliame areale) bei tuo, kad šie tyrimai suintensyvejo paskutiniuoju dešimtmečiu - atsivèrus duomenų bazèms internete. Panašios priežastys lèmé ir ilgesnes duomenų sekas analizuojamuose darbuose: terminą „klimato kaita" mini 57 \% darbų, nagrinejjusių daugiau kaip $30 \mathrm{~m}$. trukmès duomenis.

Dažniausiai (29 \% darbų) terminas „klimato kaita" vartojamas ịvade. Nemaža autorių, paminèjusių šį terminą îvade, kituose reikšminiuose skyriuose jo nebevartoja. Tai ypač būdinga antrajam nagrinèto laikotarpio dešimtmečiui (3 lentelè). Ši tendencija gali liudyti ir pastaraisiais metais juntamą rezonansinį žiniasklaidos formuojamo diskurso poveiki studentų nuomonei. Itvadas hidrometeorologų baigiamuosiuose darbuose tradiciškai suvokiamas kaip labiausiai viešas (todèl menkai mokslinio teksto pateikimo taisyklių saistomas) skyrius: juo siekiama „priartinti“ skaitytoją prie nagrinejjamos temos, čia retos nuorodos ị literatūros šaltinius, nèra paveikslų ir lentelių. Todèl „klimato kaita" itin dažnai minima ịvado pradžioje, apibūdinant bendrąsias aplinkos sąlygas ir galimas analizuojamos problemos sąsajas su jomis. Išvadose „klimato kaitos“ sąvoka vartojama rečiau (20 \% darbų), tačiau net $79 \%$ atvejų, paminejjus ši terminą išvadose, jis aptinkamas ir kituose skyriuose. Tik šešių, itin glaudžiai su šia tema susijusių, darbų autoriai terminą „klimato kaita“ mini visuose reikšminiuose skyriuose (penkiuose iš jų šis terminas vartojamas ir paties darbo ar atskirų jo skyrių pavadinimuose).

\section{APIBENDRINIMAS}

VU hidrometeorologu baigiamuju darbų struktūros ir tematikos analizè atskleidè ryškius juose tiriamų problemų turinị ir kontekstą apibūdinančių rodiklių pokyčius 1994-2013 m. laikotarpiu. Rodikliai ypač pakito antroje laikotarpio pusèje: maždaug nuo 2003-2005 m. darbuose pradèta dažniau analizuoti meteorologijos klausimus (anksčiau dominavo hidrologinès temos), naudoti stacionarių nuolatinių matavimų rezultatus, nagrinèti ilgesnes duomenų sekas, cituoti daugiau lite- ratūros šaltinių anglų kalba. Galima teigti, kad tai susiję su XX-XXI a. sandūroje ịvykusiais pokyčiais bendroje hidrometeorologinių tyrimų paradigmos schemoje, nulemtais staigaus informacinių technologijų vystymosi šuolio.

Bendrieji darbų struktūros pokyčiai paveikè ir klimato kaitos sąvokos statusą baigiamuosiuose darbuose. Reikšminiuose skyriuose apie klimato kaitą užsimenančiuose darbuose nagrinèjamos didesnès teritorijos, ilgesnès duomenų sekos, juose nenaudojama ekspedicinių tyrimų medžiaga. Nagrinejamo laikotarpio pabaigoje terminas „klimato kaita" minimas 1,6 karto dažniau nei pradžioje. Ypač imta dažniau vartoti ši terminą apibūdinant darbo tikslą ir uždavinius, tai byloja, kad gausejo konkrečių klimato kaitos rodiklių analizei skirtų darbų. Tyrimas parode, kad baigiamuosius darbus studentai linkę traktuoti kaip aukšto lygio specializuotus mokslinius tekstus ir juose nepagristai vengia vartoti savitus terminus. Akademiniam diskursui (skirtingai nei viešajam diskursui) nebūdingas termino „klimato kaita“ tapatinimas su terminais, apibūdinančiais šio reiškinio pasekmes ir indikatorius („globalus atšilimas“, „dykumèjimas“, „ekstremalių reiškinių padažnèjimas“ ir pan.). Vengiant neargumentuotos terminologijos analizei skirtose darbo dalyse, terminas „klimato kaita“ hidrometeorologų baigiamuosiuose darbuose dažniau aptinkamas darbo ịvade, kur minimi procesai nebūtinai siejami su konkrečiais tyrimų rezultatais.

Gauta 20141016

Priimta 20141117

\section{LITERATŪRA}

1. Agazzi E. 2004. Right, Wrong and Science. Amsterdam: Rodopi.

2. Anderson A. 2009. Media, politics and climate change: towards a new research agenda. Sociology Compass. 3(2): 166-182.

3. Asayama S., Ishii A. 2012. Reconstruction of the boundary between climate science and politics: The IPCC in the Japanese mass media, 1988-2007. Public Understanding of Science. 23(2): 189-203.

4. Augustinaitis A. 2004. Šiuolaikinio žinojimo sandara. Informacijos mokslai. 29: 31-45.

5. Balžekienė A., Telešienė A., Rinkevičius L. 2008. Klimato kaita: socialinio rizikos suvokimo ir žiniasklaidos diskurso Lietuvoje konfigūracijos. Sociologija. Mintis ir veiksmas. 2(22): 5-19.

6. Balžekienè A., Butkevičienè E., Rinkevičius L., Gaidys V. 2009. Ekologiniu ir technologiniu riziku 
suvokimas: Lietuvos visuomenès požiūriai ir nuostatos. Filosofija. Sociologija. 20(4): 237-249.

7. Boykoff M. T., Boykoff J. M. 2007. Climate change and journalistic norms: a case study of US massmedia coverage. Geoforum. 38: 1190-204.

8. Brossard D., Shanahan J., McComas K. 2004. Are issue-cycles culturally constructed? A comparison of French and American coverage of global climate change. Mass Communication and Society. 7(3): 359-377.

9. Doyle J. 2007. Picturing the Clima(c)tic: Greenpeace and the Representational Politics of Climate Change Communication. Science as Culture. 16: 129-50.

10. Garfield E. 1983. Citation Indexing - Its Theory and Application in Science, Technology, and Humanities. Philadelphia: ISI Press.

11. Hansen C., Johnson C. R., Pascucci V., Silva C. T. 2009. Visualization for Data-Intensive Science. In: Hey T., Tansley S., Tolle K. (ed.). The Fourth Paradigm. Redmont, Washington: Microsoft Research. 153-163.

12. Hirsch J. E. 2005. An index to quantify an individual's scientific research output. Proceedings of the National Academy of Sciences of the United States of America. 102(46): 16569-16572.

13. Hulme M. 2006. Chaotic world of climate truth. BBC News. http://news.bbc.co.uk/2/hi/science/nature/6115644.stm (last accessed 2006 2014).

14. Hunt J. R., Baidocchi D. D., Van Ingen C. 2009. Redefining Ecological Science Using Data. In: Hey T., Tansley S., Tolle K. (ed.). The Fourth Paradigm. Redmont, Washington: Microsoft Research. 21-26.

15. Jančevskaitė R, Telešienè A. 2013. Klimato kaitos diskursas Lietuvos spausdintineje ir internetineje žiniasklaidoje. Filosofija. Sociologija. 24(2): 92-99.

16. Jaspal R., Nerlich B., Koteyko N. 2013. Contesting science by appealing to its norms: readers discuss climate science in the Daily Mail. Science Communication. 35(3): 383-410.

17. Kraniauskas L. 2001. Lietuvos sociologijos istorijos bruožai (II). Sociologija. Mintis ir veiksmas. 3-4: 5-23.

18. Lietuvos geografų draugija. 2014. Geografijos istorijos Lietuvoje žinynas. http://www.lgd.lt/history (žiūrèta 20140620 ).

19. RINOVA: Rizikos suvokimas, viešoji komunikacija ir inovatyvus valdymas žiniu visuomeneje. Projekto baigiamoji ataskaita. 2009. http://rinova.ktu.lt (žiūrèta 20140620 ).

20. RisbeyJ.S. 2008. The new climate discourse: Alarmist or alarming? Global Environmental Change. 18: 26-37.
21. Šinkūnienė J. 2010. Autoriaus pozicijos raiška asmeniniais ìvardžiais rašytiniame akademiniame diskurse. Filologija. 15: 124-141.

22. Telešienė A. 2009. Klimato kaitos diskursas Lietuvoje: reikšmių konstravimas dienraščiuose. Filosofija. Sociologija. 20(4): 250-258.

23. Valiuškevičius G. 2001. Geografijos sampratos raida Lietuvoje. Geografija Lietuvoje. R. Baubinas (red.). Vilnius: Geografijos institutas, Lietuvos geografu draugijаю 12-18.

24. Vilniaus universiteto Hidrologijos ir klimatologijos katedra. Diplominiai darbai ir disertacijos. http:// www.hkk.gf.vu.lt/?page_id=34 (žiūrèta 201406 20).

25. Weingart P., Engels A., Pansegrau P. 2000. Risks of communication: discourses on climate change in science, politics, and the mass media. Public Understanding of Science. 9(3): 261-283.

\section{Gintaras Valiuškevičius}

\section{ANALYSIS OF VILNIUS UNIVERSITY HYDRO- METEOROLOGISTS' MASTER'S THESES IN THE CONTEXT OF CLIMATE CHANGE DISCOURSE}

\section{Sum mary}

The paper presents analysis of the structure of hydrometeorologists' graduate works in Vilnius University in 1994-2013. It also discusses the climate change academic discourse. The structure of analyzed works themes and the status of the climate change concept during the analyzed period have changed for the informational and technological development impact. The indicators especially changed in the second half of the period. It is related to the changes in the general paradigm of hydrometeorological research in the beginning of the twenty-first century. Around 2003-2005 these works started analyzing meteorological-climatological issues (previously hydrological themes dominated). At the same time the use of regular monitoring measurements data began to increase and longer data series were examined. In recent years significantly more theses cited literature in English.

The term "climate change" is mentioned 1.6 times more at the end of the research period than at the beginning of this period. Currently this term is increasingly used to describe the objectives and tasks of theses. The study indicates that the phrase "climate change" is often used in the introductions of works (because authors lack arguments).

Key words: climate change, academic discourse, hydrometeorology, graduate works 